\title{
Dukungan Sosial dan Kebahagiaan Lansia Penghuni Panti Sosial di Medan
}

\author{
Ummu Khuzaimah \\ Program Studi Psikologi, Fakultas Psikologi, Universitas Medan Area, Medan \\ Program Studi Psikologi, Fakultas Psikologi, Universitas Padjadjaran, Bandung \\ Yenni Anggraini \\ Program Studi Psikologi, Fakultas Psikologi, Universitas Medan Area, Medan

\section{Zahrotur Rusyda Hinduan, Hendriati Agustiani, Ahmad Gimmy Prathama Siswadi} \\ Program Studi Psikologi, Fakultas Psikologi, Universitas Padjadjaran, Bandung
}

\begin{abstract}
Abstrak. Kebahagiaan lansia di panti sosial menjadi penting ketika berbagai permasalahan hidup lansia menyertainya. Penelitian ini bertujuan untuk mengetahui hubungan antara dukungan sosial dan kebahagiaan lansia. Responden berjumlah 40 orang yang memiliki fungsi pendengaran yang baik dari kedua jenis kelamin yang berusia $\geq 60$ tahun, bebas dari diagnosis depresi, demensia atau gangguan neurologis atau psikopatologis. Sampel dipilih dengan teknik purposif. Kebahagiaan diukur dengan kuesioner yang mengacu pada indikator Happiness oleh Seligman (2002) yang terdiri dari emosi positif maupun aktivitas positif dan terbagi menjadi tiga yaitu yang ditujukan pada masa lalu (bersyukur dan memaafkan), masa depan (yakin, percaya, harapan, dan optimis) dan masa sekarang (gratifikasi dan kesenangan). Dukungan sosial diukur menggunakan skala adaptasi dari The MOS Social Support Survey oleh Sherbourne dan Stewart (1991) dengan empat dimensi skala dukungan fungsional: emosional/informasional (emotional/ informational), bantuan nyata (tangible), penuh kasih sayang (affectionate), dan interaksi sosial positif (positive social interaction). Hasil menunjukkan bahwa ada korelasi positif signifikan antara dukungan sosial dan kebahagiaan. Implikasi penelitian ini ialah pentingnya dukungan sosial bagi lansia untuk meningkatkan kebahagiaan di panti sosial.
\end{abstract}

Kata Kunci: dukungan sosial, kebahagiaan, lansia, panti sosial

\section{Social Support and Happiness among Institutionalized Older People in Medan}

Abstract. The happiness of the residents of nursing homes becomes important with the presence of various accompanying life problems. This research aims to see the relationship between social support and elderly happiness. It involves 40 respondents with good hearing of both sexes aged $\geq 60$ years, free of diagnosis of depression, dementia or neurological or psychopathological disorders. The sample is selected by a purposive technique. Happiness measurement with a questionnaire that refers to the indicator of Happiness by Seligman (2002) which consists of positive emotions or positive activities. The indicator is divided into three parts; addressed to the past (grateful and forgiving), the future (faith, believe, hope, and optimistic) and now (gratuity and pleasure). As to the social support I adapt the scale from The MOS Social Support Survey by Sherbourne and Stewart (1991) with four dimensions of functional support: emotional/informational, tangible, affectionate, and positive social interactions. The result confirms that there is a significant positive relation between social support and happiness. The implication of this research is the importance of social support for the elderly to increase happiness in social institutions.

Keywords: happiness, institutionalized older people, social support, the elderly

Korespondensi: Ummu Khuzaimah. Email: ummu@staff.uma.ac.id 
Pembangunan nasional di berbagai bidang telah berdampak positif bagi membaiknya kondisi ekonomi masyarakat secara umum dan kesehatan. Tidak mengherankan angka harapan hidup (life expectancy) telah meningkat secara nyata. Hasil Sensus Penduduk 2010 (Hariman \& Purba, 2020) menunjukkan bahwa penduduk Indonesia memiliki harapan untuk hidup hingga mencapai usia 70.7 tahun. Angka ini menunjukkan bahwa Indonesia dalam transisi menuju ageing country, yaitu negara dalam kelompok berstruktur lansia.

Penuaan merupakan indikator keberhasilan pembangunan, namun jumlah yang besar tersebut berpotensi menjadi persoalan bagi bangsa ini apabila kualitas hidup para lansianya rendah. Sebagai gambaran saat ini tercatat ada 20.5 juta jiwa lansia di Indonesia, di antaranya 2.1 juta lansia terlantar dan sebanyak 1.8 juta lansia juga berpotensi terlantar (Kementerian Sosial Republik Indonesia, 2017). Sementara itu prediksi dari Badan Pusat Statistik pada tahun 2030 jumlah lansia melonjak dua kali lipat dari jumlah lansia saat ini yaitu 40 juta jiwa. Meningkatnya jumlah kelompok lansia membutuhkan pelayanan kesehatan yang komprehensif.

Pemerintah berupaya menanggulangi permasalahan lansia terlantar melalui Unit Pelayanan Teknis (UPT) pelayanan sosial lanjut usia di setiap provinsi di bawah naungan Kementerian Sosial. Institusi ini memberikan pelayanan dan perawatan jasmani, rohani, dan sosial, serta perlindungan untuk memenuhi kebutuhan lanjut usia agar dapat menikmati taraf hidup secara wajar (Depsos RI, 2002). Meski demikian, Sulastri dan Humaedi (2017) menemukan bahwa sasaran pelayanan sosial dalam panti, termasuk yang dikelola oleh pemerintah, masih memilih lansia yang mampu mandiri dan memiliki keluarga, padahal lansia dapat dilayani melalui model layanan home care dan community care. Pelayanan dalam panti sebaiknya memilih lansia yang sudah tidak memiliki kemandirian yang tidak dapat ditangani oleh model pelayanan lain. Untuk itu, diperlukan pengembangan mekanisme penjangkauan lansia secara tepat, proses pelayanan yang relevan, penyediaan sumber daya manusia dan sarana pelayanan yang memadai.

Beberapa studi mengenai dampak positif kehidupan lansia di panti werdha telah dilakukan oleh beberapa peneliti. Studi oleh Pramesona dan Taneepanichskul (2018) mendapati bahwa kecukupan perawatan yang dirasakan dan alasan untuk tinggal di panti disorot sebagai prediktor kualitas hidup di antara lansia penghuni panti. Berdasarkan kondisi panti di Malaysia, bentuk dukungan sosial yang diterima oleh lansia adalah dukungan emosional, fisik, keuangan dan spiritual. Dampak dukungan dimaksudkan untuk meningkatkan kesejahteraan dan kebahagiaan lansia penghuni panti di Penang, Malaysia (Ghani et al., 2016). Individu lansia menyatakan rasa bahagia tinggal 
di panti dikarenakan tercukupinya kebutuhan hidupnya, pelayanan yang mewadai, dan mendapat teman yang saling mendukung (Bahkruddinsyah, 2016; Impisari, 2017; Mbeo et al, 2019; Pali, 2016).

Penelitian tentang kebahagiaan telah menarik perhatian di berbagai belahan dunia sesuai dengan tujuan psikologi positif untuk menciptakan kehidupan yang lebih baik. Dalam bukunya yang berjudul Authentic Happiness, Seligman (2002) mengungkap sebuah konsep mengenai kebahagiaan. Dalam kebahagiaan termuat emosi positif maupun aktivitas positif dan terbagi menjadi tiga yaitu yang ditujukan pada masa lalu, masa depan, dan masa sekarang. Kebahagiaan adalah salah satu tuntutan alami dan psikologis yang paling mendesak dari manusia, kanak-kanak sampai lanjut usia (Mackenzie et al., 2018), dan karena dampak utamanya pada kesehatan dan perkembangan masyarakat. Sejalan dengan perkembangan psikologi positif maka topik kebahagiaan mulai banyak diminati, termasuk kebahagiaan pada orang lanjut usia mulai menjadi perhatian akhirakhir ini (García \& Navarrro, 2018; Lara et al., 2020; Moeini et al., 2016). Kebahagiaan dapat memengaruhi diri seseorang dengan cara yang positif dan perilaku positif.. Selain itu, literatur juga menunjukkan bahwa individu yang bahagia lebih kreatif, membantu, beramal, dan percaya diri, memiliki kontrol diri yang lebih baik, dan menunjukkan kemampuan regulasi diri dan mengatasi (coping) yang lebih besar (Lyubomirsky, 2013).
Kebahagiaan di masa tua merupakan hal yang penting. Kebahagiaan sangat terkait dengan indikator kesehatan. Lansia bahagia mencerminkan lansia yang sehat. Indikator ini cukup layak digunakan sebagai pelengkap untuk mengevaluasi program promosi kesehatan lansia (Lima et al., 2012). Moeini et al. (2016) menyimpulkan pentingnya mengadopsi program untuk meningkatkan kebahagiaan pada lansia yang berguna sebagai salah satu strategi meningkatkan semua dimensi kesehatan: fisik, mental, dan sosial. Studi oleh Nassab dan Allahvirdiyani (2013) pada program meningkatkan kebahagiaan terbukti efektif menurunkan tingkat depresi lansia. Studi Hariri dan Khodami (2011) program pelatihan kebahagiaan dapat meningkatkan harapan hidup pada lansia.

Caunt et al. (2013) ingin mengetahui strategi kebahagiaan jangka panjang. Pada studi tersebut, Caunt et al. (2013) meminta 201 responden (18-84 tahun) menuliskan strategi kebahagiaan responden berdasarkan kategori enam dimensi (yaitu kepribadian, keadaan, hubungan sosial, aktivitas perilaku, aktivitas kognitif, dan aktivitas kehendak) berdasarkan pada model penyebab kebahagiaan jangka panjang oleh Lyubomirsky et al. (2005). Responden adalah responden yang bahagia dan sehat secara mental. Mayoritas tanggapan merujuk pada hubungan sosial seperti dengan keluarga, teman dan mitra, mendukung pernyataan bahwa hubungan diperlukan untuk kebahagiaan (Diener, 2009). Peneliti lain juga 
mendukung isu hubungan sosial (social ties) kaitannya dengan kebahagiaan lansia seperti dukungan sosial (Ahmadi et al., 2019; Gariépy et al, 2016; Ghani et al., 2016; Lee \& Kim, 2015; Luchesi et al., 2018; Babak Moeini et al., 2016); modal sosial (social capital) (Almasi et al., 2018; Arampatzi et al, 2018; Han, 2015; Kim et al., 2020; Oshio, 2017); social capital and social network (Arampatzi et al., 2018); relasi sosial (Aziz \& Ahmad, 2017; Waldinger \& Schulz, 2010); kepercayaan sosial (social trust) (Lu et al., 2020); kebutuhan sosial (social needs) (Buijs et al., 2020); sumber-sumber psikososial (psychosocial resources) (Lara et al, 2020).

Berdasarkan tinjauan tersebut, kebahagiaan erat kaitannya dengan lingkungan sosial yang suportif dikarenakan lansia tinggal berpisah dengan keluarga. Hal ini dapat dipahami karena berbagai kondisi terkait penuaan membuat lansia membutuhkan dukungan sekitar. Terutama lansia di panti sosial bahkan responden mengandalkan dukungan penuh dari pengasuh/perawat dan sesama lansia sebab dukungan dari keluarga umumnya tidak responden dapatkan. Studi Zulfiana (2014) pada lansia membuktikan bahwa terapi kelompok dengan teman di panti dapat meningkatkan kebahagiaan.

Dukungan sosial di panti dari teman dan pengasuh menjadi penting jika dilihat dari alasan lansia untuk datang ke panti. Studi Pali (2016) menjelaskan bahwa lansia datang ke panti untuk menghindari konflik dan agar tidak merepotkan keluarga. Hal ini menjadikan diri lansia menjadi tertekan untuk pertama kali datang ke panti. Studi oleh Keo et al. (2020) mendapati bahwa dukungan sosial secara parsial berpengaruh signifikan terhadap stres akulturasi pada individu perantau. Menurut Cohen dan Wills (Keo et al., 2020), hal tersebut dapat dipahami melalui penjelasan teori bufer stres (stress buffering), yaitu ketika individu mengalami kondisi yang menekan, dukungan sosial hadir sebagai bufer atau pelindung dari efek-efek negatif yang ditimbulkan dari situasi stres tersebut baik secara langsung maupun tidak langsung, sedangkan dalam ketidakhadiran stres dukungan sosial juga dapat berkontribusi (mainly effect) secara langsung (Thoits, 1985).

Almasi et al. (2018) menemukan urutan faktor yang memengaruhi kebahagiaan lansia yang pertama adalah social capital (termasuk dukungan sosial), berikutnya pendapatan, dan terakhir strategi adaptasi. Berdasarkan urutan kontribusinya terhadap kebahagiaan maka Ahmadi et al. (2019) menunjukkan bahwa yang lebih sedikit jumlah gangguan fisik, peningkatan dukungan sosial, status ekonomi yang lebih tinggi, lansia yang lebih muda, dan memiliki rumah pribadi dikaitkan dengan kebahagiaan yang lebih tinggi.

Dukungan sosial menjadi semakin penting bagi lansia tak terkecuali lansia yang tinggal di panti werdha. Seiring bertambahnya usia, banyak lansia berada dalam kondisi yang tidak menguntungkan. Lara et al. (2020) memperluas bukti yang ada tentang pengaruh 
kualitas hidup yang berhubungan dengan kesehatan, efikasi diri, optimisme, dan dukungan sosial pada kesejahteraan subyektif. Dukungan sosial yang tinggi dapat meningkatkan kebahagiaan lansia. Kualitas dan kuantitas dukungan dapat dianggap sebagai penentu dan prediktor kebahagiaan yang tepat bagi lansia (Moeini et al., 2018). Menurut Scott dan Roberto (Caunt et al, 2013), dukungan instrumental dan emosional secara positif dapat dikaitkan dengan kesehatan mental, dapat memberikan mekanisme perlindungan untuk mengurangi kecemasan dan kesedihan dan dapat memperkuat perasaan nilai pribadi dan harga diri di usia tua.

Beberapa penelitian terkait dukungan sosial dan kebahagiaan di panti werdha pada lansia telah dilakukan oleh beberapa peneliti di Indonesia, namun belum ada penelitian yang terdapat di Medan Binjai. Penelitian ini dengan demikian difokuskan pada setting panti werdha di Medan Binjai. Hal ini dapat dapat dibuktikan oleh data penelitian berikut. Hasil studi Amalia (2014) yang dilakukan pada Panti Werdha Pangesti Lawang di Malang menunjukkan bahwa terdapat hubungan positif signifikan kebahagiaan dan dukungan sosial pada lansia. Studi oleh Hidayah (2016) di Lembaga Sosial Tresna Werdha Nirwana Puri di Samarinda dengan pendekatan kualitatif yang melibatkan lima subjek mengungkap bahwa dukungan sosial dan kebahagiaan yang dirasakan oleh lansia berbeda-beda. Studi oleh Nurhidayah dan Agustini (2012) pada lansia di Panti Werdha
Budhi Dharma di Bekasi menunjukkan hasil bahwa dukungan sosial memiliki pengaruh positif signifikan pada kebahagiaan lansia.

Mempertimbangkan kekuatan dan kelemahan yang terdapat pada panti sosial pelayanan lanjut usia dan kondisi psikologis lansia sebagai penghuninya, peneliti ingin mengetahui apakah dukungan sosial berkorelasi dengan kebahagiaan lansia di panti, dan seberapa besar pengaruh dukungan sosial terhadap kebahagiaan lansia. Dalam usaha mencari jawaban atas keingintahuan peneliti, maka diajukan hipotesis bahwa terdapat hubungan dukungan sosial dengan kebahagiaan lansia di UPT Pelayanan Sosial Lanjut Usia Medan Binjai. Semakin tinggi dukungan sosial semakin tinggi kebahagiaan lansia, sebaliknya semakin rendah dukungan sosial maka semakin rendah kebahagiaan lansia di UPT Pelayanan Sosial Lanjut Usia Medan Binjai.

\section{Metode}

\section{Responden penelitian}

Penelitian ini adalah penelitian korelasional dengan 40 responden ( 4 pria dan 36 wanita) lanjut usia yang berpartisipasi secara sukarela dalam penelitian ini setelah mendapatkan persetujuan (menandatangani informed consent). Pengambilan sampel dilakukan dengan teknik purposif (purpossive sampling), responden dipilih tidak secara acak namun dipilih berdasarkan kriteria tertentu yaitu: berusia 60 tahun ke atas; memiliki pendengaran yang cukup baik; bebas dari 
diagnosa depresi, demensia atau gangguan neurologis atau psikopatologis berdasarkan hasil pemeriksaan kesehatan oleh dokter dan psikolog di UPT. Hal ini diberlakukan dikarenakan kondisi kebahagiaan terkait erat dengan kesehatan (Lima et al., 2012) dan menjadi "tidak bahagia" berhubungan secara signifikan dengan kondisi depresi (Luchesi et al. 2018). Penelitian ini telah diizinkan oleh pihak UPT Pelayanan Sosial Lansia Medan Binjai sebagai respon terhadap surat permintaan untuk melakukan penelitian dari Universitas "X" di Medan.

\section{Pengukuran}

Kebahagiaan diukur mengacu pada indikator Happiness oleh Seligman (2002). Dalam kebahagiaan termuat emosi positif maupun aktivitas positif dan terbagi menjadi tiga yaitu yang ditujukan pada masa lalu, masa depan, dan masa sekarang. Kebahagiaan masa lalu mencakup kepuasan, pemenuhan, dan kedamaian. Dua indikator pencapaiannya adalah rasa bersyukur dan memaafkan. Kedua konsep tersebut dapat mengubah penghayatan dan pemahaman mengenai masa lalu yang buruk menjadi lebih baik. Kebahagiaan masa kini yang sejati dapat dicapai dengan meraih sebanyak mungkin aktivitas yang lebih bersifat gratifikasi daripada pleasure. Indikator gratifikasi adalah kegiatan yang menarik minat seseorang beraktivitas seakan waktu serasa terhenti, sedangkan pleasure adalah kesenangan yang bersifat sementara. Kebahagiaan akan masa depan ditandai dengan emosi positif. Indikatornya: yakin (faith), percaya (confidance), harapan (hope), dan optimisme. Menggunakan 44 butir yang disusun berdasarkan skala likert dengan 4 poin yaitu Sangat Sesuai $=4$ sampai Sangat Tidak Sesuai $($ STS $)=4$. Penyataan skala ini disusun dalam bentuk favourable dan unfavourable.

Penelitian ini menggunakan try out terpakai, artinya data yang sudah diambil dalam uji coba skala ukur, kembali digunakan sebagai data untuk pengujian hipotesis. Hal ini dilakukan sehubungan dengan terbatasnya jumlah responden penelitian. Setelah selesai pengujian validitas butir, kemudian dilanjutkan dengan analisis reliabilitas menggunakan rumus Alpha Cronbach dengan perolehan nilai .950. Berdasarkan indeks reliabilitas tersebut, skala yang telah disusun dinyatakan dapat diandalkan untuk dapat digunakan pada saat yang lain dalam mengungkap kebahagiaan. Berdasarkan hasil uji coba alat ukur untuk skala kebahagiaan, dari 44 butir pernyataan, terdapat 8 butir yang gugur, dan 36 butir yang valid.

Dalam upaya menghindari bias maka peneliti berusaha menghindari pengukuran yang bersifat global terhadap kebahagiaan, guna meminimalisir pengaruh dari sejumlah faktor, seperti suasana hati saat ini atau lingkungan sekitarnya yang dalam beberapa kasus memengaruhi tanggapan terhadap butir. Meski demikian, di samping data kuantitatif, peneliti juga melakukan wawancara untuk memperkaya data per aspek. Shipp et al. (2009) mendukung konsep pengukuran seperti ini 
yang disebutnya dengan fokus temporal. Fokus temporal adalah perhatian individu untuk berpikir tentang masa lalu, sekarang, dan masa depan, dan konsep ini penting karena mempengaruhi bagaimana individu menggabungkan persepsi tentang pengalaman masa lalu, situasi saat ini, dan harapan dan keyakinan masa depan. Lalu diintegrasikan dalam menilai kebahagiaan saat ini (yaitu dalam beberapa hari atau minggu terakhir), kepuasan hidup di masa lalu, dan keyakinan/harapan/ optimisme terhadap masa depan.

Dukungan Sosial diukur menggunakan skala adaptasi dari The MOS Social Support Survey oleh Sherbourne dan Stewart (1991) dengan empat dimensi skala dukungan fungsional: emosional/informasi (emotional/ informational), bantuan nyata (tangible), penuh kasih sayang (affectionate), dan interaksi sosial positif (positive social interaction). Skala pengukuran dapat diandalkan (semua nilai Alpha Cronbach > .91), dan cukup stabil dari waktu ke waktu. Dukungan sosial di sini adalah persepsi lansia tentang ketersediaan dukungan sebagai bukti bahwa responden diperhatikan dan dicintai yang bersumber dari teman dan pengasuh (psikolog dan perawat). Menggunakan 18 item yang dijawab pada skala Likert 4 poin (1 = Tidak pernah sampai 4 = Selalu) yang menunjukkan frekuensi pemberian setiap jenis dukungan yang tersedia. Skor total menunjukkan persepsi atas dukungan sosial yang diperoleh. Skala dukungan sosial terbukti dapat diandalkan dengan nilai Alpha Cronbach sebesar .945.

\section{Prosedur penelitian}

Responden diberikan informasi umum mengenai tujuan utama penelitian dan meminta responden sukarela responden dengan mengajukan informed consent yang ditandatangani oleh petugas/perawat sebagai walinya. Kemudian, responden menerima informasi terperinci mengenai studi ini dan instruksi spesifik tentang cara mengisi kuesioner dengan benar. Dalam kebanyakan kasus, kuesioner diberikan secara individual karena karakteristik atau keadaan individu tersebut (misalnya, orangtua yang tidak bisa baca tulis atau ketika orang tua tidak dapat membaca karena kerusakan pada mata dan responden yang tidak dapat menulis karena kesulitan motorik). Dalam hal ini, peneliti membacakan isi kuesioner pernyataan demi pernyataan dan responden diminta menentukan pilihan jawabannya, kemudian peneliti menuliskan/menandai pada pilihan yang ditentukan responden. Kuesioner untuk setiap peserta diisi selama satu sesi. Disamping itu, dilakukan wawancara untuk menggali data tambahan dalam menjelaskan gambaran kebahagiaan per aspeknya kepada masingmasing responden.

\section{Analisis data}

Sebelum analisis data dilakukan dengan menggunakan product moment maka terlebih dahulu dilakukan uji asumsi terhadap variabel yang menjadi pusat perhatian, yaitu data variabel dukungan sosial dan kebahagiaan, yang meliputi: 
a. Uji normalitas, yaitu untuk mengetahui apakah distribusi data penelitian masingmasing variabel telah menyebar secara normal. Uji ini dilakukan dengan teknik Kolmogorov-Smirnov Goodness of fit test. Berdasarkan analisis tersebut, maka diketahui bahwa dukungan sosial dan kebahagiaan mengikuti sebaran normal yang berdistribusi sesuai dengan prinsip kurva normal. Tingkat signifikansi ditetapkan pada $p=.05$. Apabila $p>.05$ maka artinya sebaran mengikuti distribusi normal.

\section{Tabel 1}

Hasil Uji Normalitas

\begin{tabular}{lcccc}
\hline \multicolumn{1}{c}{ Variabel } & $M$ & $S D$ & K-S & $p$ \\
\hline Dukungan Sosial & 109.70 & 17.293 & 1.125 & $.159^{*}$ \\
Kebahagiaan & 103.73 & 18.98 & .860 & $.451^{*}$ \\
\hline
\end{tabular}

Catatan. $\mathrm{K}-\mathrm{S}=$ Kolmogorov-Smirnov; ${ }^{*} \mathrm{p}>.05$

Hasil uji normalitas menunjukkan skor Kolmogorov-Smirnov variabel dukungan sosial sebesar 1.125 dengan $p=.159(p>$ .05 ) yang berarti variabel dukungan sosial memliki data yang berdistribusi normal. Variabel kebahagiaan juga memiliki distribusi data yang normal dengan skor Kolmogorov Smirnov sebesar .860 dengan $p=.451(p>.05)$ yang berarti variabel ini memiliki data yang berdistribusi normal.

b. Uji linearitas, yaitu untuk mengetahui apakah data dari variabel dukungan sosial memiliki hubungan linier dengan data variabel kebahagiaan. Sebagai kriteria apabila $p<.005$ maka dinyatakan mempunyai hubungan yang linear sebagaimana yang ditampilkan dalam tabel berikut ini.

Tabel 2

Hasil Uji Linearitas

\begin{tabular}{lcc}
\hline \multicolumn{1}{c}{ Variable } & $F$ & $p$ \\
\hline $\mathrm{X}-\mathrm{Y}$ & 19.198 & $.001^{*}$ \\
\hline Catatan. $\mathrm{X}=$ dukungan sosial $; \mathrm{Y}=$ kebahagiaan $;{ }^{*} \mathrm{p}<.005$ &
\end{tabular}

\section{Hasil}

Penelitian ini bertujuan untuk mengetahui apakah dukungan sosial berkorelasi dengan kebahagiaan lansia di panti, dan seberapa besar pengaruh dukungan sosial terhadap kebahagiaan lansia. Berdasarkan hasil perhitungan korelasi Pearson Product Moment diperoleh hasil sebagai berikut:
1. Terdapat hubungan positif yang signifikan antara dukungan sosial dengan kebahagiaan pada lansia yang tinggal di UPT Pelayanan Sosial Lanjut Usia Medan Binjai $(r=.514$ dengan $p=.001 ; p<.005$ ). Ini berarti bahwa semakin tinggi dukungan sosial maka kebahagiaan lansia semakin tinggi. Demikian sebaliknya jika dukungan sosial 
rendah maka kebahagiaan pada lansia juga akan semakin rendah.

2. Adapun koefisien determinasi $\left(\mathrm{R}^{2}\right)$, hubungan antara dukungan sosial dengan kebahagiaan, adalah .265. Nilai ini tergolong moderat namun cenderung kecil, artinya peran dukungan sosial dari pengasuh dan teman masih tergolong cukup baik dalam memengaruhi kebahagiaan lansia di UPT Sosial Lanjut Usia Medan Binjai. Tabel 3 merupakan hasil perhitungan koefisien determinasi penelitian.

\section{Tabel 3}

\section{Hasil Uji Analisis Korelasi}

\begin{tabular}{|c|c|c|c|c|}
\hline Variabel & $r$ & $\mathrm{R}^{2}$ & $p$ & $E S$ \\
\hline$X-Y$ & $.514^{*}$ & .265 & .001 & $26.5 \%$ \\
\hline
\end{tabular}

Catatan. $\mathrm{X}=$ dukungan sosial $; \mathrm{Y}=$ kebahagiaan ${ }^{*} \mathrm{p}<.01$

3. Dalam upaya mengetahui kondisi dukungan sosial dan kebahagiaan pada lansia warga UPT Pelayanan Sosial Lanjut Usia Medan Binjai, maka diperhatikan besarnya bilangan simpangan baku (standar deviasi) dari masing-masing variabel. Untuk variabel dukungan sosial, nilai standar deviasi adalah sebesar 17.29 dan untuk variabel kebahagiaan adalah sebesar 18.98 sebagaimana yang ditampilkan pada Tabel 4.

\section{Tabel 4}

Hasil Perhitungan Nilai Rata-Rata Hipotetik dan Nilai Rata-Rata Empirik

\begin{tabular}{|c|c|c|c|c|}
\hline \multirow{2}{*}{ Variabel } & \multicolumn{2}{|c|}{$M$} & \multirow{2}{*}{$S D$} & \multirow{2}{*}{ Kategori } \\
\hline & Hipotetik & Empirik & & \\
\hline Dukungan Sosial & 95 & 109.70 & 17.29 & Sedang \\
\hline Kebahagiaan & 90 & 103.73 & 18.98 & Sedang \\
\hline
\end{tabular}

Dari besarnya bilangan standar deviasi $(S D)$, untuk masing-masing variabel dukungan sosial dan kebahagiaan, apabila rata-rata hipotetik lebih kecil daripada rata-rata empirik dimana selisihnya melebihi bilangan satu standar deviasi, maka responden penelitian memiliki dukungan sosial yang tinggi, sedangkan apabila rata-rata hipotetik lebih besar daripada rata-rata empirik dimana selisihnya melebihi bilangan satu standar deviasi maka responden penelitian memiliki dukungan sosial yang rendah. Berdasarkan perbandingan antara kedua rata-rata (hipotetik dan empirik) dan selisihnya diketahui bahwa responden penelitian ini memiliki tingkat dukungan sosial yang sedang. Demikian pula dengan tingkat kebahagiaan tergolong sedang. Dengan begitu diketahui bahwa tingkat kebahagiaan maupun tingkat dukungan di 
UPT Pelayanan Sosial Lanjut Usia Medan Binjai ini sama sama tergolong sedang, artinya lingkungan sosial di panti sosial ini cukup suportif terhadap lansia. Sementara itu suasana hati penghuni juga cukup bahagia.

4. Di samping hasil penelitian terdapat beberapa temuan penelitian berdasarkan wawancara dan observasi per aspek kebahagiaan: emosi positif yang ditujukan ke masa lalu, kegiatan positif saat ini, dan emosi positif terhadap masa depan. Dari ketiga aspek kebahagiaan tersebut yang menonjol adalah emosi positif yang ditujukan untuk masa lalu yaitu indikatornya rasa syukur. Sebagaimana bapak $\mathrm{H}$, salah satu penghuni panti sosial berusia 62 tahun, mengatakan: "Kalau dibilang saya sekarang udah senang $B u$... Dulu bayangkan saya narik beca tapi sudah tua tenaga sudah kurang alhamdulillah saya tidak narik beca lagi, tapi masih bisa makan, nda perlu narik beca. Dulu saya susah bu mau makan belum tentu ada uangnya." Muncul rasa syukur pada responden yang mengaku bahagia setiap kali membandingkan keadaan saat ini dengan keadaan di masa lalu. Emosi positif juga mendominasi karena saat ini waktu luang dapat diisinya dengan kegiatan positif yang dia sukai (gratifikasi, sebuah indikator kebahagiaan saat ini) “Waktu luang saya isi dengan membaca buku. Buku apa saja saya baca. Terkadang juga bercocok tanam. Di sini ada yang suka kasi donasi, bingkisan, saya simpan nanti kalau cucu saya datang dia pasti senang". Individu yang bahagia cenderung terlihat optimis menjalani masa depan. Rasa syukur tersebut tampaknya dapat menularkan optimisme (indikator kebahagiaan masa depan) individu dalam menjalani masa depannya di panti.

5. Diantara jenis dukungan yang ada: emosional/informasi (emotional) informational); bantuan nyata (tangible); penuh kasih sayang (affectionate); dan interaksi sosial positif (positive social interaction), berdasarkan hasil wawancara dan observasi ditemukan bahwa dukungan berupa bantuan nyata (tangible) adalah jenis yang paling menonjol seperti pemenuhan kebutuhan dasar makan dan minum serta perawatan di saat sakit. Sebagaimana ibu S usia 71 tahun mengatakan: "Saat sakit diurusi sama perawat, dibersihkan, dimandikan, semua perawat di sini baik, ngomongnya baik, sabar, lembut tutur katanya". Dukungan lainnya yang ditemukan adalah dukungan spiritual berupa siraman rohani (masing-masing agama) dan yasinan (khusus muslim) sebagai bentuk pemenuhan kebutuhan religi yang khas di masa tua. Ibu M usia 65 tahun lebih menyenangi kegiatan spiritual, responden mengatakan: "Kalau olah raga bagus tapi kadang males karena capek, merasa terpaksa apalagi pake ancaman mereka bilangnya kalau malas senam nanti dikeluarkan dari panti. Tapi kita di sini bisa 
rajin beribadah, shalat, ngaji. Kalau pengajian satu minggu sekali setiap Selasa kami biasa menantikan nanti pergi bersama sama dengan kawan-kawan di sini". Bentuk kegiatan ini dinilai cukup signifikan memengaruhi kebahagiaan yang dilaporkan para lansia.

\section{Pembahasan}

Berdasarkan hasil penelitian, ada hubungan positif yang signifikan antara dukungan sosial dengan kebahagiaan pada lansia yang tinggal di UPT Pelayanan Sosial Lanjut Usia Medan Binjai. Ini berarti bahwa semakin banyak dukungan sosial maka kebahagiaan lansia semakin tinggi. Demikian sebaliknya jika sedikit dukungan sosial maka kebahagiaan pada lansia juga akan semakin rendah. Hasil penelitian ini mendukung apa yang sebelumnya ditemukan oleh Moeini et al. (2016) bahwa dukungan sosial yang tinggi dapat meningkatkan kebahagiaan lansia. Selanjutnya dikatakan bahwa kualitas dan kuantitas dukungan dapat dianggap sebagai penentu dan prediktor kebahagiaan yang tepat bagi lansia. Senada hal itu Diener (2009) juga menuliskan bahwa salah satu sumber kebahagiaan yang paling penting adalah hubungan pribadi, persahabatan, pernikahan, keintiman, dan dukungan sosial. Dukungan sosial adalah fenomena yang menarik dalam psikologi karena berpotensi dapat membantu memahami hubungan antara individu dan dukungan sosial responden. Hubungan ini melibatkan berbagai aspek dukungan sosial yang diterima oleh individu atau komunitas sosial dari orang lain atau lingkungan sosial yang lebih luas. Bahkan dalam kultur Indonesia, alaminya dukungan sosial adalah hubungan sosial. Jadi untuk menjelaskan bagaimana dukungan sosial menolong kesejahteraan yang berkelanjutan, seseorang harus memahami bagaimana peran hubungan (the "social self") dapat memengaruhi keadaan psikologis. Cohen et al. (2000) mengatakan proses-proses social self ini dapat mendatangkan keamanan, kerinduan, cinta, dan harga diri. Dengan demikian, secara umum dukungan sosial telah dianggap bermanfaat baik secara langsung maupun tidak langsung terhadap kebahagiaan lansia di panti.

Dari penelitian ini juga diketahui bahwa tingkat kebahagiaan maupun tingkat dukungan di UPT Pelayanan Sosial Lanjut Usia Medan Binjai ini sama sama tergolong sedang, artinya lingkungan sosial di UPT cukup suportif terhadap lansia. Sementara itu suasana hati penghuni juga cukup bahagia. Kebahagiaan merepresentasikan suatu bentuk interaksi antara manusia dan lingkungan. Dalam hal ini seseorang mungkin bahagia sendiri, tetapi di sisi lain responden juga bisa bahagia karena orang lain. Ini juga memberikan fakta lain bahwa kebahagiaan bukanlah egoistis tetapi dapat dibagi dengan orang lain dan lingkungan. Ketika seseorang berada dalam suasana hati yang positif, orang-orang lebih menyukainya. Persahabatan, cinta dan hubungan masyarakat lebih aman. Emosi positif membuat keadaan 
mental menjadi toleran dan kreatif, lebih terbuka terhadap ide dan pengalaman baru (Seligman, 2002).

Berdasarkan wawancara tambahan diketahui baik responden laki-laki maupun perempuan melaporkan hal yang sama tentang kebahagiaan yaitu bahwa saat ini responden lebih berbahagia (kebahagiaan saat ini lebih diakui) dibandingkan pada masa lalu. Dari segi gender tampaknya tidak ada perbedaan yang signifikan yang berpengaruh terhadap kebahagiaan. Penelitian terbaru sebelumnya juga menunjukkan bahwa faktor sosialdemografi memiliki dampak yang lebih rendah pada kebahagiaan dibandingkan dengan variabel lain. Umur, jenis kelamin, dan ras meski digabungkan hanya menjelaskan hingga $10 \%$ dari kebahagiaan (Diener, 2009). Menariknya, kebahagiaan tampaknya lebih terkait dengan latar belakang responden masuk ke panti sosial yang beragam. Pada responden pria mengatakan pada masa lalu responden terpaksa harus bekerja keras mencari nafkah (misal, sebagai penarik beca) sedangkan saat ini responden bersyukur bisa makan tanpa harus terus mengayuh becak di saat usia responden pun semakin senja. Sebagian responden pria lainnya masuk ke panti sosial karena pilihan pribadi responden dan ada pula yang atas keinginan anaknya sehingga responden tidak punya pilihan selain mengikut (kelompok ini umumnya responden tidak bahagia). Adapun pada responden wanita dikarenakan responden pernah terlantar, ada yang berkonflik dengan keluarga sehingga datang sendiri ke panti sosial, ada juga yang memilih tinggal di panti karena sakit dan tidak ingin merepotkan keluarga, ada lagi yang dibohongi keluarga dikatakan akan dibawa jalan-jalan ternyata dibawa ke panti sosial (kelompok ini umumnya sulit menerima keberadaan responden di panti sehingga responden tidak bahagia), dan sebagian lainnya karena faktor kesepian sehingga responden memilih tinggal di panti. Dalam studi yang dilakukan oleh Yuliastuti dan Anggoro (2017) ditemukan bahwa orangtua yang tinggal sendirian akan memulai kehidupan baru di panti. Sebaliknya, responden yang tinggal di panti dikarenakan penyakit kronis atau tidak ingin membebani keluarga responden; responden kurang menikmati kualitas hidup karena mengalami kesulitan untuk beradaptasi dengan lingkungan baru (Yuliastuti \& Anggoro, 2017).

Ditinjau per aspek kebahagiaan, pada responden yang mengaku bahagia saat ini juga memiliki rasa optimisme yang lebih baik terhadap masa yang akan datang. Hasil wawancara per aspek kebahagiaan menunjukkan bahwa umumnya masa lalu disikapi dengan bersyukur dan responden mengakui merasakan peningkatan rasa bahagia. Sementara keadaan saat ini disikapi dan diisi dengan beragam cara: sebagian melakukan hobi (seperti bercocok tanam), sebagian kecil menunjukkan kemampuan azan, menjadi imam, membaca Al-Qur'an. Sebagian lain membuat makanan ringan dengan menjemur 
kerak nasi (namun hobi ini tidak didukung oleh petugas karena dinilai melanggar aturan kebersihan sehingga menimbulkan rasa kurang bahagia yang responden laporkan). Selain itu beberapa responden mengeluhkan bentuk pemaksaan pada kegiatan yang kurang disukai seperti senam yang dilakukan sebanyak dua kali dalam seminggu. Adapun program yang tampak banyak disukai adalah kegiatan rohani (pengajian). Terakhir, pandangan terhadap masa depan dinilai cukup optimis disebabkan adanya keterjaminan pemenuhan kebutuhan tingkat sandang dan pangan serta perawatan di saat sakit. Berdasarkan hasil analisis (kualitatif) per aspek terlihat bahwa kebahagiaan responden saat ini merupakan fungsi dari kualitas hidup (perbandingan antara saat ini dengan masa lalu) dan dukungan sosial yang dimediasi oleh rasa syukur. Yuliastuti dan Anggoro (2017) mengakui pentingnya untuk mengeksplorasi kualitas hidup orangtua di panti.

Analisis kualitatif menunjukkan bahwa kebahagiaan saat ini belum terlihat menonjol disebabkan kegiatan yang sifatnya gratifikasi tidak sepenuhnya didukung oleh pengelola. Sementara kegiatan yang terjadwal seperti senam masih kurang dapat menarik minat pesertanya. Kabar baiknya adalah para lansia cukup antusias mengikuti pengajian rutin di panti. Hal ini ternyata merupakan bentuk dukungan sosial (spiritual) yang signifikan dibutuhkan bagi para lansia. Responden membutuhkan ilmu agama sebagai penuntun responden dalam menyikapi kehidupan seharihari serta mempersiapkan kematian dan bekal di kehidupan setelahnya. Responden yang aktif di pengajian terlihat lebih bahagia, lebih mampu bersosialisasi, kurang mengeluh dan berkonflik. Menurut Abraham Maslow (1971) di akhir perjalanan hidupnya seseorang menemukan realisasi penuh dalam memberikan diri pada sesuatu di luar dirinya (misalnya, dalam altruisme atau spiritualitas). Responden menyamakan ini dengan keinginan untuk mencapai yang tak terbatas. "Transendensi mengacu pada tingkat kesadaran manusia yang paling tinggi dan paling inklusif atau holistik, berperilaku dan berhubungan, sebagai tujuan daripada sarana, untuk diri sendiri, orang lain, manusia pada umumnya, spesies lain, alam, dan kosmos (Wikipedia.com, 2020).

Peneliti tertarik membahas temuan aspek-aspek kebahagiaan ini dari teori hirarki kebutuhan Maslow (1943). Berdasarkan pemaparan di atas tampaknya kebutuhan dasar (basic needs) berupa kebutuhan fisiologis (Physiological needs) dan keamanan (safety needs) lansia di Panti terpenuhi dengan baik. Hirarki selanjutnya adalah kebutuhan psikologis (psychological needs) berupa cinta dan penghargaan (belongingness and love dan esteem needs). Belongingness and love mengarah pada hubungan interpersonal yang melibatkan perasaan memiliki. Menurut Maslow, manusia memiliki kebutuhan afektif akan rasa memiliki dan penerimaan di antara kelompok sosial. Meski demikian, bagi beberapa 
individu kebutuhan akan harga diri (esteem needs) lebih penting daripada kebutuhan untuk memiliki (ini lebih terlihat pada kelompok pria); dan untuk orang lain, kebutuhan akan pemenuhan kreatif dapat menggantikan bahkan kebutuhan yang paling dasar. Esteem menyajikan keinginan khas manusia untuk diterima dan dihargai oleh orang lain. Oleh karena itu penting memiliki suatu hobi untuk meningkatkan rasa berharga. Aktivitas ini memberi orang tersebut rasa kontribusi atau nilai, sekaligus dapat mengatasi rasa bosan dan kesepian. Agaknya penekanan di sini lebih bersifat individual differencies untuk dapat diperhatikan oleh pihak pengelola Panti terhadap kompetensi atau aktivitas yang diminati masing-masing individu. Diharapkan lagi, lansia juga dapat mencapai hierarki tertinggi yaitu aktualisasi diri. Maslow menggambarkan ini sebagai keinginan untuk mencapai segala sesuatu yang seseorang bisa, untuk menjadi yang terbaik dari yang responden bisa. Individu yang termotivasi untuk mengejar tujuan ini mencari dan memahami bagaimana kebutuhan, hubungan, dan perasaan diri responden diekspresikan melalui perilaku. Oleh karenanya sangat dibutuhkan dukungan fungsional dari lingkungan: bantuan nyata, penuh kasih sayang, emosional/informasi bahwa responden berharga, dan interaksi sosial yang positif.

Selanjutnya, berdasarkan koefisien determinasi $\left(\mathrm{R}^{2}\right)$, hubungan antara dukungan sosial dengan kebahagiaan adalah $\mathrm{R}^{2}=.265$.
Nilai ini tergolong moderat namun cenderung kecil, artinya peran dukungan sosial dari pengasuh dan teman masih tergolong cukup memberikan kebahagiaan kepada lansia di UPT Sosial Lanjut Usia Medan Binjai. Sejalan dengan pendapat Moeini et al. (2018) bahwa kebahagiaan juga dipengaruhi oleh dukungan sosial sebagai faktor eksternal. Hal ini menunjukkan bahwa kebahagiaan lansia di UPT Sosial Lanjut Usia Medan Binjai dipengaruhi oleh dukungan sosial dari teman dan pengasuh sebesar $26.5 \%$, sedangkan $73.5 \%$ sisanya dipengaruhi oleh faktor lain yang dapat mempengaruhi kebahagiaan seperti kebersyukuran, kepribadian, spiritualitas atau religiusitas, budaya, perkawinan, pertemanan, dan kesehatan yang tidak diteliti dalam studi ini.

Peneliti berkeyakinan bahwa dukungan sosial dari keluarga masih sangat responden harapkan tentunya. Hal ini juga berdasarkan laporan secara lisan dari beberapa responden bahwa responden ingin sekali dikunjungi atau mengunjungi anggota keluarga atau kerabat responden. Ada kerinduan yang mendalam yang jika pikiran ini muncul menimbulkan perasaan sedih dan keterasingan. Menurut Seligman (2002), kebahagiaan moderat adalah karena kurangnya kepuasan hidup dan kurangnya berpikir positif tentang segala sesuatu. Meski demikian pada faktanya kebanyakan dari responden melaporkan (secara lisan) bahwa responden sangat bersyukur telah berada di sini jika dibandingkan dengan sebelumnya. Responden mulai dapat menerima keadaan 
responden dan berpikir untuk menjadi lebih baik dari kehidupan masa lalu responden. Hal ini sejalan dengan Argyle (1987) yang berpendapat bahwa kepuasan hidup akan terjadi jika ada kecocokan antara apa yang diinginkan seseorang dan kenyataan yang dihadapi sekarang baik menyangkut prestasi maupun dimensi lain. Dalam hal mempromosikan dukungan sosial kepada lansia di panti sosial, perlu digalakkan lebih banyak program yang melibatkan kolaborasi generasi muda dan populasi tua. Responden yang sudah lanjut usia yang tidak memiliki anak akan senang memiliki seseorang untuk mendengarkan dan berbicara dengannya.

Dapat dikatakan bahwa secara umum warga memandang ketersediaan dukungan baik dari teman dan pengasuh cukup baik. Berdasarkan pengamatan peneliti, adanya kepedulian diantara responden, saling memperhatikan dan mengingatkan. Disamping itu, hubungan sosial responden dengan pengasuh juga terlihat positif. Pengasuh terlihat merawat dengan sabar, responden bertutur kata yang baik dan lembut, mampu mendengarkan dan menenangkan, perhatian, dan mengajak tertawa. Pramesona dan Taneepanichskul (2018) mendapati bahwa kecukupan perawatan yang dirasakan dan alasan untuk tinggal di nursing-home (home care) disorot sebagai prediktor kualitas hidup di antara lansia penghuni NH. Sarafino (2009) menyatakan bahwa dukungan sosial mengacu pada memberikan kenyamanan kepada orang lain, merawatnya atau mengobatinya. Dukungan sosial dapat membuat seseorang merasa nyaman, didukung, dicintai ketika individu berada dalam keadaan stres. Oleh karena itu, meningkatkan layanan perawatan kesehatan yang memadai dan mengembangkan strategi perawatan diperlukan untuk mempertahankan kebahagiaan lansia penghuni panti sosial.

Demikian pula dengan kondisi kebahagiaan, melalui perhitungan yang sama dengan di atas, hasil penelitian ini menunjukkan bahwa lansia disebut berada dalam kategori "bahagia". Berdasarkan hasil wawancara dengan para lansia, diketahui responden merasa lebih bahagia di sini dibandingkan dengan tempat sebelumnya. Responden mengakui bersyukur bahwa di masa tua yang semakin lemah responden mendapatkan lingkungan yang aman bagi responden, perawatan yang memadai, ketersediaan makanan, sarana ibadah dan spiritual, dan latihan fisik. Hal ini sekaligus menjadi temuan dalam penelitian ini bahwa ada hal lain muncul dengan adanya dukungan tersebut, yaitu suatu rasa syukur. Bertocci dan Millard mendefinisikan syukur sebagai emosi yang menyenangkan yaitu kesediaan untuk menyadari bahwa seseorang telah menerima manfaat dari kebaikan seseorang (Gulliford et al, 2013). Emosi itu secara positif menyebar dan terkait secara teratur mengalami emosiemosi positif lainnya (Wood \& Tarrier, 2010).

Hal ini senada dengan apa yang didapati oleh para ahli bahwa berpikir bersyukur meningkatkan suasana hati. Bersyukur 
membantu mengatasi stres dan mengurangi pengalaman emosi beracun (experience of toxic emotions) akibat perbandingan sosial (Emmons \& Mishra, 2011); dan, rasa syukur tidak hanya berdampak langsung pada kualitas hidup, tetapi juga memiliki efek tidak langsung melalui stres yang dirasakan pada kesehatan mental (Valikhani et al., 2019). Portocarrero et al. (2020) menemukan bahwa rasa syukur disposisional adalah salah satu prediktor kepribadian terbaik (dispositional gratitude is a one of the best personality predictors).

Menurut Seligman (2002) ada dua konsep penting untuk mencapai kebahagiaan masa lalu ialah rasa bersyukur dan memaafkan. Kedua konsep tersebut dapat mengubah penghayatan dan pemahaman mengenai masa lalu yang buruk menjadi lebih baik

Hasil-hasil studi di atas mendukung teori bahwa rasa syukur merupakan sifat afektif yang penting bagi kesejahteraan subyektif. Sebagaimana firman Allah dalam Surat Ibrahim ayat 7-8: “... Jika kamu bersyukur (atas nikmat) karuniaKu) pasti akan Aku tambahkan kepadamu. Dan jika kamu mengingkarinya sesungguhnya azabKu amatlah pedih". Berdasarkan firman tersebut dapat dipahami bahwa kebahagiaan adalah pilihan. Kebahagiaan dapat diperoleh dengan cara bersyukur atas apa yang ada. Demikian pula jika seseorang lupa akan bersyukur malah sebaliknya larut dalam kesedihan dan kepedihan hidup, maka dengan sendirinya akan mengalami siksaan batin sehingga membuatnya semakin jauh dari kebahagiaan. Sebagaimana dicatat oleh McAdams (Portocarrero et al., 2020), banyak orang dewasa yang sangat baik hati yang memprioritaskan pengasuhan dan menjaga dunia. Dengan demikian, kebaikan hati (generativitas) dapat berinteraksi dengan syukur untuk memperkuat kesejahteraan. Mengingat hubungan positif antara generativitas dan usia, diharapkan seiring bertambahnya usia semakin bertambah banyak bersyukur sehingga meningkatkan kesejahteraan (kebahagiaan) individu.

Hal lain yang didapati dalam penelitian ini adalah faktor yang memengaruhi kebahagiaan lansia di panti ini salah satunya adalah dukungan pengelola terhadap kegiatan spiritual. Lansia diajak untuk mengikuti pengajian setiap minggunya dan kegiatan membaca surah Yasin setiap malam Jumat. Bentuk-bentuk siraman rohani ini diakui para lansia memberi dampak positif bagi ketenangan batin responden dan sebagai bekal untuk pulang ke kampung akhirat. Karisna dan Pihasniwati (2019) mendapati bahwa pelatihan relaksasi dzikir dapat meningkatkan kebahagiaan lansia (studi pada lansia di Rumah Pelayanan Sosial Lanjut Usia Terlantar (RPSLUT) Budhi Dharma Yogyakarta). Hal ini membuktikan bahwa partisipasi dalam kegiatan keagamaan juga menjadi faktor penting untuk meningkatkan kebahagiaan lanjut usia (lansia). Disaat usia menua terdapat gap antara ekspektasi dan kenyataan sumberdaya yang tidak cukup untuk 
membuat wellbeing sehingga individu mengekspresikan kebutuhan spiritual (Büssing et al, 2013). Kebutuhan religius muncul sebagai wujud dari kepercayaan beragama dan kelelahan, duka cita dan kepuasan hidup yang rendah (Erichsen \& Büssing, 2013). Keimanan efektif dalam melawan keputusasaan dan depresi (Basith, 2016). Sejumlah inisiatif dan program telah diambil oleh lembaga pemerintah dan non-pemerintah untuk mendukung orangtua di panti seperti dukungan sosial dan kegiatan keagamaan. Ini akan membantu mengurangi kecemasan responden, perasaan penolakan dan isolasi sosial. Seperti yang didukung dalam penelitian Soriano et al. (2016), menemukan pelembagaan dan spiritualitas memiliki dampak langsung pada dimensi kualitas hidup orangtua. Temuan penelitian ini menemukan bahwa beberapa responden yang dirawat di panti menderita kesepian dan depresi karena tidak adanya dukungan emosional dari keluarga dan anakanak. Sementara itu, spiritualitas adalah prediktor utama kualitas hidup orangtua di panti, karena dapat membantu meningkatkan harga diri dan kepuasan hidup dengan melibatkan kegiatan keagamaan (Soriano et al, 2016). Oleh karena itu responden menyarankan sejumlah kegiatan keagamaan dan sosial untuk ditawarkan kepada orangtua di panti.

Keterbatasan dalam penelitian ini adalah jumlah sampel yang kurang memadai, analisis yang sederhana dan data demografi yang cenderung terabaikan. Data berasal dari tahun
2016 sehingga saat ini peneliti hanya dapat menampilkan hasil penelitian dengan apa adanya berdasarkan data yang tersedia. Meski demikian, data hasil wawancara sebagai pelengkap cukup membantu dalam memperkaya analisis kebahagiaan lansia di UPT Pelayanan Sosial Lanjut Usia Medan Binjai secara sistematis. Untuk peneliti yang akan datang ada baiknya menggabungkan data lansia dari berbagai jenis panti sosial lanjut usia baik milik pemerintah maupun swasta untuk mendapatkan jumlah sampel yang lebih banyak, sekaligus dapat diteliti perbedaan keduanya dan pengaruhnya terhadap kesehatan fisk, mental, sosial, dan spiritual pada lansia. Meskipun keseluruhan populasi penelitian ini berjumlah 172 orang, namun yang memungkinkan diambil datanya sangat terbatas disebabkan kondisi kesehatan. Fakta ini menunjukkan bahwa tingkat kualitas hidup dan kesehatan lansia di negara ini masih rendah. Hal ini juga menandakan bahwa kebutuhan orangtua akan beberapa bentuk akomodasi alternatif dan fasilitas perawatan perumahan (nursing home) sejenis panti sosial diperkirakan akan terus meningkat. Oleh karena itu penelitian dengan tema-tema terkait kualitas hidup, kesehatan, dan kebahagiaan pada lansia penghuni panti dan sejenisnya penting untuk terus ditingkatkan. Terlebih lagi penting adanya program-program yang dirancang untuk responden dapat menyalurkan hobi, bakat, mengekspresikan nilai-nilai yang mendukung gratifikasi dan aktualisasi diri lansia. Mehr et al. (2019) 
membuktikan bahwa partisipasi aktif dalam program pendidikan gaya hidup sehat dapat meningkatkan kebahagiaan dan kepuasan hidup di kalangan lansia.

\section{Simpulan}

Berdasarkan hasil yang diperoleh dalam penelitian ini disimpulkan bahwa hipotesis yang diajukan dalam penelitian ini diterima. Hasil penelitian telah mendukung argumen bahwa dukungan sosial terkait langsung dengan kebahagiaan. Kontribusi efektif variabel dukungan sosial dengan kebahagiaan lansia sebesar 26,5\%. Hasil ini menunjukkan terdapat $73,5 \%$ dari faktor lain yang memengaruhi kebahagiaan lansia yang tidak diungkapkan dalam penelitian ini, yaitu faktor eksternal lain seperti dukungan keluarga, faktor internal seperti kepribadian, spiritualitas dan demografis seperti kesehatan, status pernikahan, pendidikan, dan jenis kelamin, dan sosial ekonomi. Selain hasil di atas, dalam penelitian ini ditemukan bahwa rasa syukur dan kepuasan atas layanan (dukungan) yang difasilitasi panti diduga sebagai penyumbang kebahagiaan lansia di UPT Pelayanan Sosial Lanjut Usia Medan Binjai.

\section{Saran}

Berdasarkan temuan ini disarankan agar penelitian selanjutnya dapat melakukan uji model kebahagiaan lansia yang tinggal di institusi sejenis dengan menambahkan variabel kesyukuran (sebagai faktor internal) disamping dukungan sosial (sebagai faktor eksternal), tentunya dengan skala yang lebih luas, misalnya mencakup UPT Pelayanan Sosial Lanjut Usia se-Sumatera Utara sehingga jumlah sampel menjadi jauh lebih banyak. Saran untuk lembaga agar meningkatkan layanan kesehatan, mengembangkan strategi perawatan, memfasilitasi penyaluran hobi, minat dan bakat lansia, serta program-program kerohanian.

\section{Referensi}

Ahmadi, A., Soleimani, M., Pahlevan Sharif, S., \& Motalebi, S. (2019). Association between perceived social support and happiness among community-dwelling elderly adult. The Journal of Qazvin University of Medical Sciences, 23(4), 320-331. https://doi.org/10.32598/ JQUMS.23.4.320

Almasi, M., Mahmoudiani, S., \& Jafari, M. (2018). Factors associated with feelings of happiness among the elderly. Iran Journal of Nursing, 72(29), 23 - 32. https:// doi.org/10.29252/ijn.27.92.23

Amalia, S. (2014). Kebahagiaan personal dan dukungan sosial pada lansia: Studi pada lansia di komunitas keluarga dan panti jompo. Jurnal Ilmiah Kesehatan Media Husada, 3(1), 53-58. https://doi.org/ 10.33475/jikmh.v3i1.147

Arampatzi, E., Burger, M. J., \& Novik, N. (2018). Social network sites, individual social capital and happiness. Journal of Happiness Studies, 19(1), 99-122. https:/ /doi.org/10.1007/s10902-016-9808-z

Argyle, M. (1987). The psychology of happiness. Methuen.

Aziz, N. A., \& Ahmad, Y. (2017). The quality of life of aging population: A study among older person who received long term care services at old folks home, Penang [Special Issue]. Journal of Administrative Science, 14(3), 1 - 18. https:// j a s.u i tm . e d u.m y / i m a ge s / SPECIALEDITIONVOL3_2017/5.pdf 
Bahkruddinsyah, R. (2016). Makna hidup dan arti kebahagiaan pada lansia di Panti Werdha Nirwana Puri Samarinda. EJournal Psikologi, 4(4), 431-445. http:/ /e-journals.unmul.ac.id/index.php/ psikoneo/article/view/3931

Basith, A. (2016). Hubungan antara religiusitas dengan authentic happiness pada Jama'ah Maulid wat Ta'lim Riyadlul Jannah Malang [Skripsi] [Universitas Islam Negeri Maulana Malik Ibrahim]. http://etheses.uin-malang.ac.id/id/ eprint/2812

Buijs, V., Jeronimus, B., Lodder, G, Steverink, N., \& Jonge, P. (2020). Social needs and happiness: A life course perspective. Journal of Happiness Studies, 1-45. https:/ /doi.org/10.1007/s10902-020-00287-9

Büssing, A., Janko, A., Baumann, K., Hvidt, N. C., \& Kopf, A. (2013). Spiritual needs among patients with chronic pain diseases and cancer living in a secular society. Pain Medicine (Malden, Mass.), 14(9), 13621373. https://doi.org/10.1111/ pme.12198

Caunt, B. S., Franklin, J., Brodaty, N. E., \& Brodaty, H. (2013). Exploring the causes of subjective well-being: A content analysis of peoples' recipes for long-term happiness. Journal of Happiness Studies, 14(2), 475-499. https://doi.org/ 10.1007/s10902-012-9339-1

Cohen, S., Underwood, L. G., \& Gottlieb, B. H. (2000). Social support measurement and intervention: A guide for health and science scientist. Oxford University Press.

Depsos RI. (2002). Standarisasi pelayanan kesejahteraan sosial panti sosial tresna werdha (PSTW).

Diener, E. (2009). The science of well-being the collected works of Ed Diener. Social Indicators Research Series, 37. https:// doi.org/10.1007/978-90-481-2350-6

Emmons, R. A., \& Mishra, A. (2011). Designing positive psychology: Taking stock and moving forward. In K. M. Sheldon, T. B. Kashdan, \& M. F. Steger (Eds.), Why gratitude enhances well-being: What we know, what we need to know (pp. 248262). University Press. https://doi.org/ 10.1093 / a c p r o f: o s o / 9780195373585.003.0016.

Erichsen, N.-B., \& Büssing, A. (2013). Spiritual needs of elderly living in residential/ nursing homes. Evidence-Based Complementary and Alternative Medicine/: ECAM, 2013(3), 1-10. https:/ /doi.org/10.1155/2013/913247

García, L. M. R., \& Navarrro, J. M. R. (2018). The impact of quality of life on the health of older people from a multidimensional perspective. Journal of Aging Research, 2018(9), 1-7. https://doi.org/10.1155/ 2018/4086294

Gariépy, G., Honkaniemi, H., \& Quesnel-Vallée, A. (2016). Social support and protection from depression: Systematic review of current findings in Western countries. The British Journal of Psychiatry, 209(4), 284-293. https://doi.org/10.1192/ bjp.bp.115.169094

Ghani, N., Noordin, N., \& Zulkifli, N. (2016). Social support for the elderly at darul hanan nursing home, Penang, Malaysia [Unpublished work].

Gulliford, L., Morgan, B., \& Kristjánsson, K. (2013). Recent work on the concept of gratitude in philosophy and psychology. The Journal of Value Inquiry, 47(3), 285317. https://doi.org/10.1007/s10790013-9387-8

Han, S. (2015). Social capital and subjective happiness: Which contexts matter? Journal of Happiness Studies, 16(1), 241255. https://doi.org/10.1007/s10902014-9506-7

Hariman, A. I., \& Purba, H. S. (2020). Statistik penduduk lanjut usia provinsi Sumatera Utara 2019. https://sumut.bps.go.id/publication/ $\begin{array}{lllllllllll}2 & 0 & 2 & 0 & / & 0 & 9 & / & 1 & 4 & /\end{array}$ 1529 c 68 a 348 f 19 f 81 f 31 e $1 \mathrm{ff} /$ statistik-penduduk-lanjut-usiaprovinsi-sumatera-utara-2019.html 
Hariri, M., \& Khodami, N. (2011). A study of the efficacy of teaching happiness based on the Fordyce method to elderly people on their life expectancy. Procedia - Social and Behavioral Sciences, 30(2011), 1412-1415. https://doi.org/10.1016/ j.sbspro.2011.10.275

Hidayah, S. (2016). Dukungan sosial dan kebahagiaan pada lansia yang tinggal di UPTD Panti Sosial. Psikoborneo: Jurnal Ilmiah Psikologi, 4(3). http://ejournals.unmul.ac.id/index.php/ psikoneo/article/view/4091

Impisari, I. (2017). Makna kebahagiaan pada lansia muslim yang tinggal di Panti Tresna Werdha Teratai Palembang. Jurnal Intelektualita: Keislaman, Sosial dan Sains, 6(2), 211-228. https://doi.org/ 10.19109/intelektualita.v6i2.1607

Karisna, N., \& Pihasniwati, P. (2019). Peningkatan kebahagiaan lansia dengan pelatihan relaksasi dzikir di rumah pelayanan sosial lanjut usia terlantar Budhi Dharma. Jurnal Pemberdayaan Masyarakat: Media Pemikiran dan Dakwah Pembangunan, 3(1), 141 - 160. https://doi.org/10.14421/ jpm.2019.031-07

Kementerian Sosial Republik Indonesia. (2017). Kebijakan Kemensos untuk Kesejahteraan Sosial Lansia. https:// www.kemsos.go.id

Keo, J. J., Kristinawati, W., \& Setiawan, A. (2020). Dukungan sosial, ketangguhan pribadi, dan stres akulturasi mahasiswa Nusa Tenggara Timur di Salatiga. Psikologika, 25(1), 15 - 28. https://doi.org/ $10.20885 /$ psikologika

Kim, A., Ryu, J., Lee, C., Kim, K.-M., \& Heo, J. (2020). Sport participation and happiness among older adults: A mediating role of social capital. Journal of Happiness Studies. https://doi.org/ 10.1007/s10902-020-00288-8

Lara, E., Martín-María, N., Forsman, A. K., Cresswell-Smith, J., Donisi, V., Ådnanes, M., Kaasbøll, J., Melby, L., Nordmyr, J., Nyholm,
L., Rabbi, L., Amaddeo, F., \& Miret, M. (2020). Understanding the multidimensional mental well-being in late life: Evidence from the perspective of the oldest old population. Journal of Happiness Studies, 21(2), 465-484. https://doi.org/ 10.1007/s10902-019-00090-1

Lara, R., Vázquez, M. L., Ogallar, A., \& GodoyIzquierdo, D. (2020). Psychosocial resources for hedonic balance, life satisfaction and happiness in the elderly: A path analysis. International Journal of Environmental Research and Public Health, 17(16), 5684. https://doi.org/ 10.3390/ijerph17165684

Lee, H. K., \& Kim, H. K. (2015). Factors influencing on happiness in relation to the aging of elderly. International Journal of Applied Engineering Research, 10, 38403-38411.

Lima, M. G., Barros, M. B. de A., \& Alves, M. C. G. P. (2012). Happiness in the elderly: An epidemiological approach in the ISACamp 2008 study. Cadernos de saude publica, 28(12), 2280-2292. https:// do i.org / 10.1590 / s 0102 311x2012001400007

Lu, H., Tong, P., \& Zhu, R. (2020). Longitudinal evidence on social trust and happiness in China: Causal effects and mechanisms. Journal of Happiness Studies, 21(5), 1841-1858. https://doi.org/10.1007/ s10902-019-00159-x

Luchesi, B. M., de Oliveira, N. A., de Morais, D., de Paula Pessoa, R. M., Pavarini, S. C. I., \& Chagas, M. H. N. (2018). Factors associated with happiness in the elderly persons living in the community. Archives of Gerontology and Geriatrics, 74, 83-87. h ttps://doi.org/10.1016/ j.archger.2017.10.006

Lyubomirsky, S. (2013). The myths of happiness: What should make you happy, but doesn't, what shouldn't make you happy, but does. Penguin Press.

Lyubomirsky, S., Sheldon, K. M., \& Schkade, D. (2005). Pursuing happiness: The 
architecture of sustainable change. Review of General Psychology, 9(2), 111131. https://doi.org/10.1037/10892680.9.2.111.

Mackenzie, C. S., Karaoylas, E. C., \& Starzyk, K. B. (2018). Lifespan differences in a self determination theory model of Eudaimonia: A cross-sectional survey of younger, middle-aged, and older adults. Journal of Happiness Studies: An Interdisciplinary Forum on Subjective Well-Being, 19(8), 2465-2487. https:// doi.org/10.1007/s10902-017-9932-4

Maslow, A. H. (1943). A theory of human motivation. Psychological Review, 50(4), 370-396. https://doi.org/10.1037/ h0054346

Mbeo, A. B., Keraf, M. K. P. A., \& Anakaka, D. L. (2019). Kebahagiaan lansia di panti sosial. Journal of Health and Behavioral Science, 1(3), 166-178. https://doi.org/ 10.35508/jhbs.v1i3.2096

Mehr, M. M., Zamani-Alavijeh, F., Hasanzadeh, A., \& Fasihi, T. (2019). Effect of healthy lifestyle educational programs on happiness and life satisfaction in the elderly: A randomized controlled trial study. Iranian Journal of Ageing, 13(4), 440-451. https://doi.org/10.32598/ SIJA.13.4.440

Moeini, B, Barati, M., Farhadian, M., \& Ara, M. H. (2018). The association between social support and happiness among elderly in Iran. Korean Journal of Family Medicine, 3(4), 260. https://doi.org/10.4082/ kjfm.17.0121

Moeini, Babak, Barati, M., Farhadian, M., Babamiri, M., \& Ara, M. (2016). Happiness and its related factors among the elderly in Hamadan (Iran): A cross sectional study. Avicenna Journal of Neuro Psycho Physiology, In Press. https:/ /doi.org/10.5812/ajnpp.57782

Nassab, Z. K., \& Allahvirdiyani, K. (2013). The effects of fordyce's happiness training on decreasing depression among elderly women. Procedia - Social and Behavioral
Sciences, 84, 501-503. https://doi.org/ 10.1016/j.sbspro.2013.06.592

Nurhidayah, S., \& Agustini, R. (2012). Kebahagiaan lansia ditinjau dari dukungan sosial dan spiritualitas. SOUL: Jurnal Pemikiran Dan Penelitian Psikologi, 5(2), 15-32. http:// jurnal.unismabekasi.ac.id/index.php/ soul/article/view/627

Oshio, T. (2017). Which is more relevant for perceived happiness, individual-level or area-level social capital? A multilevel mediation analysis. Journal of Happiness Studies, 18, 765-783. http:// jurnal.unismabekasi.ac.id/index.php/ soul/article/view/627

Pali, C. (2016). Gambaran kebahagiaan pada lansia yang memilih tinggal di Panti Werdha. Jurnal E-Biomedik (EBm), 4(1), 1-6.

Portocarrero, F. F., Gonzalez, K., \& EkemaAgbaw, M. (2020). A meta-analytic review of the relationship between dispositional gratitude and well-being. Personality and Individual Differences, 164, 110101. https://doi.org/https:// doi.org/10.1016/j.paid.2020.110101

Pramesona, B., \& Taneepanichskul, S. (2018). Factors influencing the quality of life among Indonesian elderly: A nursing home- based cross-sectional survey. Journal of Health Research, 32(5), 326333. https://doi.org/10.1108/JHR-082018-037

Sarafino, E. P. (2009). Health psychology: The biopsychosocial interactions (5th ed.). Wiley.

Seligman, M. E. P. (2002). Authentic happiness: Using the new positive psychology to realize your potential for lasting fulfillment. Free Press.

Sherbourne, C. D., \& Stewart, A. L. (1991). The MOS social support survey. Social Science \& Medicine (1982), 32(6), 705-714. https://doi.org/10.1016/027 79536(91)90150-b 
Shipp, A. J., Edwards, J. R., \& Lambert, L. S. (2009). Conceptualization and measurement of temporal focus: The subjective experience of the past, present, and future. Organizational Behavior and Human Decision Processes, 110(1), 1-22. https:/ /doi.org/10.1016/j.obhdp.2009.05.001

Soriano, C. A. F., Sarmiento, W. D., Songco, F. J. G., Macindo, J. R. B., \& Conde, A. R. (2016). Socio-demographics, spirituality, and quality of life among communitydwelling and institutionalized older adults: A structural equation model. Archives of Gerontology and Geriatrics, 66, 176-182. https://doi.org/10.1016/ j.archger.2016.05.011

Sulastri, S., \& Humaedi, S. (2017). Pelayanan lanjut usia terlantar dalam panti. Prosiding KS: Riset \& PKM UNPAD, 4(1), 1 - 140. https://doi.org/10.24198/ jppm.v4i1.14225

Thoits, P. A. (1985). Social support and psychological well-being: Theoretical possibilities. In I. G. et al Sarason (Ed.), Social Support: Theory, Research and Aplications. Martinus Nijhoff Publishers.

Valikhani, A., Ahmadnia, F., Karimi, A., \& Mills, P. (2019). The relationship between dispositional gratitude and quality of life: The mediating role of perceived stress and mental health. Personality and Individual Differences, 141, 40-46. https://doi.org/ 10.1016/j.paid.2018.12.014
Waldinger, R. J., \& Schulz, M. S. (2010). What's love got to do with it? Social functioning, perceived health, and daily happiness in married octogenarians. Psychology and Aging, 25(2), 422-431. https://doi.org/ $10.1037 / \mathrm{a} 0019087$

Wikipedia.com. (2020). Maslow's hierarchy of needs. https://en.wikipedia.org/wiki/ Maslow\%27s_hierarchy_of_needs\# Social_belonging

Wood, A. M., \& Tarrier, N. (2010). Positive clinical psychology: A new vision and strategy for integrated research and practice. Clinical Psychology Review, 30(7), 819-829. https://doi.org/ 10.1016/j.cpr.2010.06.003

Yuliastuti, C., \& Anggoro, S.D, 2017. The overview of the elderly lifestyle profile in Surabaya. Jurnal Kesehatan Masyarakat, 12(2), 304-313. https://doi.org/ 10.15294/kemas.v15i3.21282

Zulfiana, U. (2014). Meningkatkan kebahagiaan lansia di panti wreda melalui psikoterapi positif dalam kelompok. Jurnal Sains dan Praktik Psikologi, 2(3), 256-267. http:// ejournal.umm.ac.id/index.php/jspp/ article/view/2889

Received 18 September 2020 Revised 4 December 2020 Accepted 5 January 2021 